\title{
AKTIVITAS ANTIBAKTERI DAN ANTIOKSIDAN EKSTRAK Streptomyces sp. DAN Exserohilum rostratum YANG DIKULTIVASI PADA TIGA JENIS MEDIUM PERTUMBUHAN
}

\author{
Antioxidant and Antibacterial Activity of \\ Streptomyces sp. and Exserohilum rostratum Extract Cultivated in \\ Three Different Growth Media
}

\author{
Ekowati Chasanah ${ }^{1 *}$, Nuning Mahmudah Noor ${ }^{2}$, Yenny Risjani ${ }^{2}$, dan Ariyanti Suhita Dewi ${ }^{1}$ \\ ${ }^{1}$ Peneliti pada Balai Besar Penelitian dan Pengembangan Pengolahan Produk dan Bioteknologi Kelautan dan Perikanan, \\ Balitbang KP, KKP \\ ${ }^{2}$ Politeknik Lampung, Lampung \\ * Korespondensi Penulis: Ekowati Chasanah, JI. K.S. Tubun Petamburan VI, Jakarta Pusat 10260. \\ E-mail: ekowati_ch@yahoo.com
}

\begin{abstract}
ABSTRAK
Penelitian ini dilakukan untuk mengeksplorasi potensi ekstrak Streptomyces sp. dan Exserohilum rostratum sebagai agen antibakteri dan antioksidan. Kedua isolat tersebut merupakan hasil isolasi dari penelitian terdahulu. Eksplorasi bioaktivitas kedua mikroba dikaji dengan menggunakan tiga macam media pertumbuhan yaitu Malt Extract Agar (MEA), Minimal Fungal Medium (MFM) dan Glucose Pepton Yeast extract (GPY). Analisis produksi bahan aktif dilakukan setiap 2 minggu selama 10 minggu kultivasi. Hasil penelitian menunjukkan bahwa kedua isolat tersebut memiliki potensi untuk digunakan sebagai bahan untuk mempertahankan bakteri patogen agar tidak meningkat atau berkembang, atau sebagai bahan anti quorum sensing. Kemampuan penghambatan bakteri uji sebesar 2-3 siklus log. Ekstrak kedua mikroba tidak memiliki potensi sebagai penghasil antioksidan. Identifikasi pendahuluan terhadap jenis senyawa aktif yang terkandung dalam ekstrak pekat Streptomyces sp. dan Exserohilum rostratum berdasarkan spektra NMR berturut-turut diduga termasuk dalam golongan alkaloid dan peptida.
\end{abstract}

KATA KUNCI: antioksidan, antibakteri, mikroba, kultivasi, media pertumbuhan

\section{ABSTRACT}

This study was carried out to explore the potency of Streptomyces sp. dan Exserohilum rostratum extracts as antibacterial and antioxidant agents. Both isolates were obtained from previous research. Exploration of their bioactivities was assessed by using three cultivation media, i.e Malt Extract Agar (MEA), Minimal Fungal Medium (MFM) and Glucose Pepton Yeast extract (GPY). Analysis on the production of bioactive metabolites was conducted every 2 weeks for 10 weeks of cultivation. Results showed that both microbes exhibited potency of antiquorum sensing material having the ability to retard growth of the microbes by 2-3 log cycle. Both of the microbes extracts were not potential for antioxidant. Preliminary identification on the active substances of Streptomyces sp. and Exserohilum rostratum extracts by means of NMR suggested the presence of alkaloid and peptide, respectively.

KEYWORDS: antioxidant, antibacteria, microbes, cultivation, growth media

\section{PENDAHULUAN}

Di antara biota laut, invertebrata laut selama ini dilaporkan merupakan jenis yang paling kaya akan senyawa bioaktif, dan beberapa di antaranya telah sampai ke berbagai pengujian sebelum tahap pengembangan ke industri. Namun demikian, masalah kurangnya bahan baku menjadi kendala dalam pengembangan selanjutnya karena invertebrata laut, sebagaimana biota laut lain ditemukan dalam jumlah yang terbatas dan laju pertumbuhan rendah, serta rendemen bahan aktif yang sangat rendah. Salah satu terobosan untuk mendapatkan bahan baku bagi produksi senyawa bioaktif yang bersifat lestari adalah 
dengan mencari mikroba yang berasosiasi dengan biota penghasil bahan aktif tersebut. Beberapa hasil riset menunjukkan bahwa bahan aktif yang dihasilkan oleh biota laut ternyata dihasilkan oleh mikroba yang berasosiasi dengannya (Zhang \& Son, 2007).

Penelitian terdahulu menunjukkan bahwa beberapa mikroba yang berasosiasi dengan spons berhasil diisolasi dari perairan P. Lombok dan 2 mikroba di antaranya aktif menghambat pertumbuhan sel kanker (Chasanah et al., 2006). Identifikasi mikroba tersebut memperlihatkan bahwa isolat tersebut memiliki kemiripan 99\% dengan Streptomyces sp. dan Exserohilum rostratum (Chasanah et al., 2009). Penelitian ini dilakukan untuk mengeksplorasi bioaktivitas kedua mikroba tersebut di atas sebagai penghasil senyawa antibakteri dan antioksidan. Dengan banyaknya kasus resistensi mikroba patogen, kebutuhan akan antibiotik baru yang efektif terutama dari produk alami merupakan tantangan baru yang saat ini dihadapi dunia. Pencarian mikroba dengan potensi berbagai bioaktivitas masih merupakan fokus penelitian, dan salah satu strateginya adalah mengoptimalkan satu sumber mikroba dengan beberapa produk metabolit yang memiliki bioaktivitas melalui berbagai kombinasi media dan lingkungan kultivasi mikroba tersebut (Meletiadis et al., 2001; Bode et al., 2002).

Tiga media yang mewakili media kaya nutrisi yaitu Malt Extract Agar (MEA), media dengan nutrisi sedang Glucose Pepton Yeast extract (GPY) dan media dengan nutrisi rendah yaitu Minimal Fungal Medium (MFM) digunakan dalam studi ini untuk melihat kesesuaiannya dalam memproduksi senyawa bioaktif tersebut. Media dan lingkungan tumbuh mikroba sangat mempengaruhi kecepatan pertumbuhan, jenis dan jumlah senyawa metabolit yang dihasilkan. Modifikasi keduanya sangat disarankan untuk mendapatkan senyawa target ataupun senyawa baru (Bode et al., 2002). Beberapa hipotesis menyebutkan bahwa metabolit aktif akan dihasilkan mikroba ketika dikultivasi pada media yang miskin, namun demikian, studi terdahulu mendapatkan bahwa media kaya seperti MEA mampu menghasilkan jumlah ekstrak dan bioaktivitas terhadap 3 jenis sel kanker untuk Streptomyces sp. dan 1 jenis sel kanker untuk E. rostratum (Chasanah et al., 2009). Pratitis et al. (2010) melaporkan ketika Aspergillus ustus MWF 26-08 dikultivasi pada media yang berlainan, maka diperoleh pula bioaktivitas yang berlainan, yaitu media miskin MFM mendorong diproduksinya senyawa antikanker, sedangkan media kaya MEB mampu mendorong diproduksinya senyawa aktif antioksidan. Media SWS yang berisi pepton soya dan pati larut air telah digunakan untuk memproduksi senyawa antikanker (Nursid et al., 2010). Tujuan penelitian ini adalah untuk mendapatkan informasi potensi Streptomyces sp. dan Exserohilum rostratum dalam memproduksi metabolit aktif antibakteri dan antioksidan ketika dikultivasi pada 3 jenis media. Prediksi awal senyawa aktif akan dilihat dari profil ekstrak pada NMR.

\section{BAHAN DAN METODE}

\section{Mikroba}

Mikroba yang digunakan adalah Streptomyces sp. dan Exserohilum rostratum yang telah berhasil diisolasi sebelumnya (Chasanah et al., 2009), yang disimpan dalam bentuk sediaan beku dalam gliserol $20 \%$. $\left(-70^{\circ} \mathrm{C}\right)$. Isolat tersebut disegarkan dengan cara memasukkan 500 ì L isolat dalam gliserol 20\% ke dalam tabung reaksi yang telah diisi 5 ì L malt ekstrak (ME) cair dan dibiarkan pada suhu ruang $\left(27-30^{\circ} \mathrm{C}\right)$ selama 6 hari atau sampai mikroba tumbuh. Mikroba tersebut kemudian digores pada media padat Malt Extract Agar (MEA). Bakteri uji yang digunakan adalah Vibrio parahaemolyticus dan Pseudomonas aeruginosa, yang berturut-turut merupakan bakteri patogen yang biasa ada di seafood dan perusak makanan. Kedua bakteri uji tersebut merupakan koleksi BBP4B-KP.

\section{Media}

Media yang digunakan dalam penelitian ini adalah media padat Malt Extract Agar (MEA), media cair Malt Extract Broth (MEB), Minimal Fungal Medium (MFM) dan Glucose Pepton Yeast extract (GPY). Pembuatan media dilakukan menurut metode Strainer (1990) dan Mahyidin (2008). Pembuatan Artificial Sea Water (ASW) mengikuti metode Strainer (1990).

\section{Kultivasi/Fermentasi Mikroba}

Kultivasi/fermentasi dilakukan dalam media cair (100 $\mathrm{mL}$ dalam botol bervolume $1 \mathrm{~L}$ ) MEB, MFM, dan GPY selama 0, 2, 4, 6, 8, dan 10 minggu untuk tiap isolat. Starter disiapkan dengan menumbuhkan mikroba dengan cara menggores secara rapat dengan ose pada media padat MEA dan diinkubasi selama 5 hari. Sebanyak 1/4 bagian agar di petridisk yang telah ditumbuhi mikroba digunakan sebagai starter dan dikultivasi pada media kultivasi cair pada suhu ruang, tanpa agitasi. Sampling dilakukan setiap 0, 2, 4, 6, 8 , dan 10 minggu. Perubahan warna media selama kultivasi kapang diamati dan dibandingkan dengan media kontrol yaitu media tanpa penambahan mikroba. Percobaan dirancang secara faktorial dengan perbedaan waktu dan media fermentasi sebagai 
faktornya dengan 2 kali ulangan. Data dianalisis dengan analysis of variance (ANOVA) menggunakan program MINITAB 14.0.

\section{Ekstraksi Metabolit Sekunder}

Proses ekstraksi dimulai dengan mencampur larutan hasil fermentasi dengan etil asetat dengan perbandingan $1: 2$, menggunakan stirer selama 12 jam, kemudian disonikasi selama 25 menit. Pemisahan campuran dilakukan dengan corong pisah, lapisan organik (atas) dikumpulkan, dipekatkan dengan rotary evaporator dan dikeringkan dengan freeze dryer untuk memperoleh ekstrak kering.

\section{Pengujian Bioaktivitas Metabolit Sekunder}

Pengujian bioaktivitas metabolit sekunder meliputi uji antioksidan dan antibakteri. Uji antioksidan dilakukan dengan menggunakan DPPH assay menurut metode Blois (1958) dan uji antibakteri dengan menggunakan metode turbidimetri, yang selanjutnya dilakukan pengecekan dengan penghitungan total plate count memakai cawan petri (Jeon \& Kim, 2000) dengan modifikasi. Pada pengujian antibakteri ini, bakteri uji disiapkan dengan cara mengambil 1 ose bakteri uji dari agar miring, ditumbuhkan dalam medium Nutrient Broth (NB), dan diinkubasikan selama 24 jam pada suhu $37^{\circ} \mathrm{C}$. Sebanyak 100 ì L biakan bakteri ini ditumbuhkan lagi di tabung reaksi yang berisi medium NB sebanyak $4,9 \mathrm{~mL}$ selama 24 jam pada suhu $37^{\circ} \mathrm{C}$, dan diukur ODnya pada 600 $\mathrm{nm}$. Setelah itu, ekstrak kering Streptomyces sp. dan E. rostratum sebanyak $100 \mathrm{ppm}$ (dalam aquadest steril) dimasukkan ke dalam media diinkubasi selama 48 jam, dan selanjutnya diukur lagi OD pada $600 \mathrm{~nm}$. Kontrol dibuat sama tetapi tanpa ekstrak uji. Pengurangan angka absorbansi menandakan terjadinya pengurangan jumlah bakteri oleh ekstrak kering Streptomyces sp. dan E. rostratum, yang selanjutnya dikuantifikasikan dengan cara mengukur jumlah bakteri dengan cawan petri yang berisi medium padat NA. Seri pengenceran dilakukan agar jumlah bakteri terhitung masuk dalam kisaran 30-300 cfu setiap cawan petri.

\section{Identifikasi Awal Golongan Senyawa Aktif}

Pemisahan ekstrak pekat dilakukan secara kromatografi menggunakan open-column method dan High Performace Liquid Chromatography (HPLC). Ekstrak pekat difraksinasi menggunakan kolom LH2O dengan pelarut metanol murni. Pemisahan lebih lanjut dilakukan dengan menggunakan HPLC (kolom reversed-phase C18 Shimadzu $150 \mathrm{~mm} \times 2 \mathrm{~mm}$; pelarut gradien asetonitril- air; detektor dual UV). Identifikasi golongan senyawa aktif dilakukan menggunakan NMR (Jeol $500 \mathrm{MHz}$; pelarut $\mathrm{CDCl}_{3}$ ).

\section{HASIL DAN BAHASAN}

\section{Produksi Ekstrak}

Penggunaan media yang berbeda dalam proses fermentasi mikroba dimaksudkan untuk mengetahui jenis media yang sesuai untuk pertumbuhan dan menghasilkan metabolit aktif antibakteri dan antioksidan bagi kedua mikroba tersebut. Jenis media akan mempengaruhi kecepatan mikroba tersebut tumbuh dan menghasilkan metabolit aktif. Glukosa dan pati merupakan sumber karbon, dan pada beberapa kasus, pertumbuhan menjadi sangat bagus ketika yeast extract digunakan sebagai satu-satunya sumber nitrogen seperti pada kasus kultivasi Actinomycetes yang mampu memproduksi senyawa antikanker (Suthindhiran \& Kannabiran, 2009). Dalam penelitian ini, media yang digunakan yaitu MEB yang dikategorikan media kaya mengandung 0,3\% ekstrak malt, $0,3 \%$ yeast extract dan 0,5\% pepton, sedangkan media GPY yang dikategorikan media sedang berisi $0,1 \%$ glukosa, $0,05 \%$ soybean, $0,01 \%$ yeast extract, dan MFM (media miskin) berisi 0,02\% yeast extract dan $0,1 \%$ soluble starch.

Pengamatan secara visual pada larutan fermentasi juga dilakukan dengan mengamati warna media setiap 2 minggu untuk mengetahui perubahan yang terjadi pada media selama proses fermentasi. Perubahan warna media menunjukkan perubahan media akibat hasil metabolisme mikroba yang ditumbuhkan. Hasil pengamatan warna media dan jumlah ekstrak berdasarkan jenis media dan waktu fermentasi disajikan dalam Tabel 1.

Dari Tabel 1 terlihat bahwa warna media berubah seiring dengan waktu fermentasi. Warna media tampak semakin pekat pada minggu keenam sesuai dengan banyaknya metabolit sekunder yang dihasilkan. Bahan aktif dari isolat Streptomyces sp. terlihat pekat kehitaman pada minggu keenam dan berkurang pada minggu kedelapan hingga kesepuluh. Streptomyces sp. diduga memproduksi metabolit sekunder secara optimum pada minggu keenam pada media GPY. Pengamatan pada E. rostratum menunjukkan bahwa warna paling pekat juga diperoleh pada minggu keenam dengan warna kuning dan kuning keruh pada media MEB. Pada kedua media tersebut, mikroba menghasilkan metabolit yang mampu menyebabkan perubahan warna sebagai produk hasil metabolisme maksimal pada minggu ke enam yang diikuti dengan pengurangan intensitas warna (Tabel 1). Hasil pengamatan jumlah rendemen bahan aktif yang diperoleh dari kedua mikroba juga mencapai maksimal pada minggu tersebut (minggu ke-6) ketika dikultivasi pada MFM dan GPY, tetapi pada media MEB, rendemen terbesar terjadi pada minggu ke-10. 
Tabel 1. Rendemen ekstrak kasar (g) dan warna media yang dihasilkan oleh mikroba. Angka yang ditebalkan menunjukkan jumlah rendemen tertinggi.

Table 1. Extracts yield (g) and media color produced by microbes. Highest yields is indicated by bold values

\begin{tabular}{|c|c|c|c|c|c|c|c|c|c|c|c|c|}
\hline \multirow{3}{*}{$\begin{array}{l}\text { Minggul } \\
\text { Weeks }\end{array}$} & \multicolumn{4}{|c|}{ Media MEB/MEB Media } & \multicolumn{4}{|c|}{ Media MFM/MFM Media } & \multicolumn{4}{|c|}{ Media GPYIGPY Media } \\
\hline & \multicolumn{2}{|c|}{$\begin{array}{l}\text { Rendemen* }^{*}(g) / \\
\text { Yield }(g)\end{array}$} & \multicolumn{2}{|c|}{ Warna/Color } & \multicolumn{2}{|c|}{$\begin{array}{l}\text { Rendemen }^{*}(g) / \\
\text { Yield }(g)\end{array}$} & \multicolumn{2}{|c|}{ Warna/Color } & \multicolumn{2}{|c|}{$\begin{array}{l}\text { Rendemen }^{*}(g) / \\
\text { Yield }(g)\end{array}$} & \multicolumn{2}{|c|}{ Warna/Color } \\
\hline & s & $E$ & $\mathbf{S}$ & $E$ & $\mathbf{S}$ & $\mathbf{E}$ & $\mathbf{S}$ & $E$ & $S$ & $E$ & $S$ & $E$ \\
\hline 0 & 1.2 & 1.2 & $=$ & $=$ & 0.9 & 1.2 & $=$ & $=$ & 0.3 & 1.2 & $=$ & $=$ \\
\hline 2 & 6.8 & 4.6 & + & + & 4.5 & 4.4 & + & + & 4.6 & 4.9 & + & + \\
\hline 4 & 8.9 & 4.4 & +++ & ++ & 6.2 & 6.2 & + & + & 5.6 & 4.8 & ++ & ++ \\
\hline 6 & 8.9 & 10.1 & ++++ & +++ & 8.1 & 7.8 & ++ & ++ & 11.7 & 5.3 & ++ & ++ \\
\hline 8 & 5.7 & 5.6 & +++ & ++ & 2.2 & 2.1 & + & + & 1.8 & 2.8 & ++ & ++ \\
\hline 10 & 11.9 & 24.0 & ++ & + & 4.3 & 2.2 & + & + & 3.1 & 3.4 & + & + \\
\hline
\end{tabular}

Keterangan/Note:

* $\quad$ Rendemen ekstrak ( $\mathrm{g}$ ) diukur dari berat ekstrak setelah pemekatan dengan rotary evaporator, nitrovapor dan freeze dryer/Yield of extract was calculated as the weight of extract after concentrated by rotary evaporator, nitrovapor and freeze dryer

S Streptomyces sp.

E Exserohilum rostratum

= sama dengan media kontrol yaitu putih kekuningan/similar to control media, e.g yellowish opaque

$+\quad$ agak kehitaman/kekuningan dibandingkan media kontrol/somewhat black/yellow compared to control media ++ sedikit kehitaman/kekuningan dibandingkan media kontrol/slightly black/yellow compared to control media +++ hitam/kuning dibandingkan media kontrol/black/yellow compared to control media

Secara statistik ditunjukkan bahwa lama kultivasi mempengaruhi jumlah ekstrak $(P<0,05)$. Semakin lama proses fermentasi maka semakin bertambah rendemen ekstrak metabolit kapang yang ditunjukkan juga dengan perubahan warna menjadi lebih pekat sampai waktu tertentu (minggu ke-6) dan akan diikuti oleh pengurangan rendemen dan intensitas warna setelah waktu tersebut. Untuk mikroba yang dikultivasi pada MEB, rendemen mengalami kenaikan lagi pada minggu ke-10 tetapi tidak warna larutan fermentasinya, yang menandakan bahwa metabolit yang disekresikan kemungkinan lain dengan metabolit yang disekresikan pada kultivasi sampai dengan minggu ke-6. Warna media awal adalah sama putih kekuningan, tetapi setelah kedua mikroba ditumbuhkan maka warna media berubah akibat metabolit yang dihasilkan oleh kedua mikroba. Metabolit yang dihasilkan oleh Streptomyces sp. merubah warna media menjadi kehitaman, sedangkan metabolit yang dihasilkan oleh E. rostratum menyebabkan warna media menjadi semakin kuning yang akan menjadi kuning pekat. Pengurangan intensitas warna setelah waktu puncak yaitu minggu ke- 6 diduga akibat terjadinya perubahan jumlah dan komposisi metabolit yang diakibatkan oleh perombakan sebagian metabolit yang telah dihasilkan untuk pertahanan hidup mikroba yang masih mampu bertahan. Rendemen terbesar diperoleh pada minggu ke-6 untuk media MFM dan GPY dan minggu ke-10 untuk medium MEA.

\section{Aktivitas Antioksidan}

Pengukuran aktifitas antioksidan terhadap metabolit sekunder dilakukan dengan menggunakan metode DPPH yang merupakan substrat untuk mempelajari mekanisme pengikatan radikal bebas pada beberapa senyawa fenolik, flavonoid dan polifenol (Auroman \& Coppet, 1997). Hasil pengukuran DPPH terhadap kedua ekstrak isolat menunjukkan bahwa perbedaan jenis isolat, jenis media dan waktu kultivasi mempengaruhi nilai penghambatan radikal bebas $(P<0,05)$. Aktivitas antioksidan dari masing-masing ekstrak isolat yang dinyatakan sebagai nilai IC ${ }_{50}$ (Tabel 2) masih jauh lebih besar dari keaktifan suatu bahan sebagai antioksidan menurut United States Food and Drug Association (US FDA), yang berarti metabolit sekunder yang dihasilkan dari kedua isolat memiliki aktivitas antioksidan yang sangat lemah sehingga tidak berpotensi sebagai penghasil antioksidan. Suatu bahan aktif dikategorikan berpotensi sebagai antioksidan apabila memiliki nilai hambat $I C_{50}$ sebesar 
Tabel 2. Aktivitas antioksidan ( $\left(\mathrm{C}_{50}\right)$ ekstrak kasar mikroba

Table 2. Antioxidant activities $\left(\mathrm{IC}_{50}\right)$ of crude extracts from microbes

\begin{tabular}{|c|c|c|c|c|c|c|}
\hline \multirow{3}{*}{$\begin{array}{l}\text { Waktu Fermentasi } \\
\text { (minggu)/ } \\
\text { Fermentation Time } \\
\text { (weeks) }\end{array}$} & \multirow{2}{*}{\multicolumn{2}{|c|}{$\begin{array}{l}\text { Media MEB } \\
\mathrm{IC}_{50}(\mathrm{ppm})\end{array}$}} & \multirow{2}{*}{\multicolumn{2}{|c|}{$\frac{\text { MFM }}{\text { IC }_{50}(\mathrm{ppm})}$}} & \multirow{2}{*}{\multicolumn{2}{|c|}{$\frac{\text { Media GPY }}{\text { IC }_{50}(\mathrm{ppm})}$}} \\
\hline & & & & & & \\
\hline & s & $E$ & s & E & $\mathbf{s}$ & $E$ \\
\hline 0 & - & - & - & - & - & - \\
\hline 2 & 1009.6 & 524.3 & 1287.0 & 3064.4 & 7753.6 & 696.0 \\
\hline 4 & 3594 & 478.9 & 3469.0 & 1803.6 & 988.9 & 3430.0 \\
\hline 6 & 456.5 & 17835.4 & 1815.4 & 507.2 & 980.3 & 696.0 \\
\hline 8 & 882.8 & 478.9 & 812.5 & 2282 & 4297.9 & 2989.0 \\
\hline 10 & 1033.6 & 46364.9 & 1643.1 & 586.7 & 2810.8 & 840.1 \\
\hline
\end{tabular}

Keterangan/Note:

S Streptomyces sp.

E Exserohilum rostratum

20 ppm untuk ekstrak kasar (FDA, 2003 dalam Li et al., 2006). Hal ini diperkuat dengan hasil uji menggunakan NMR terhadap ekstrak kasar yang menunjukkan tidak dimilikinya gugus fenol yang memungkinkan terjadinya deprotonasi radikal bebas dalam menghambat reaksi propagasi lebih lanjut (Gambar 5 dan 6).

\section{Pengujian Antibakteri}

Analisis ANOVA menunjukkan bahwa perbedaan jenis isolat penghasil metabolit, jenis media dan waktu fermentasi memberikan pengaruh yang sangat signifikan terhadap penghambatan/kematian bakteri uji V. parahaemolyticus $(P<0,05)$. Dari Gambar 1 terlihat Streptomyces sp yang dikultivasi pada minggu ke-6 dengan menggunakan ke-3 media mampu menghasilkan ekstrak dengan bioaktivitas antibakteri V. parahaemolyticus terbaik, sedangkan media MEB mampu menghasilkan bioaktivitas antibakteri yang sama sejak minggu ke-2 dan ke-4, sedangkan medium MFM menghasilkan ekstrak dengan bioaktivitas mulai minggu ke-4 (Gambar 1). Dari data

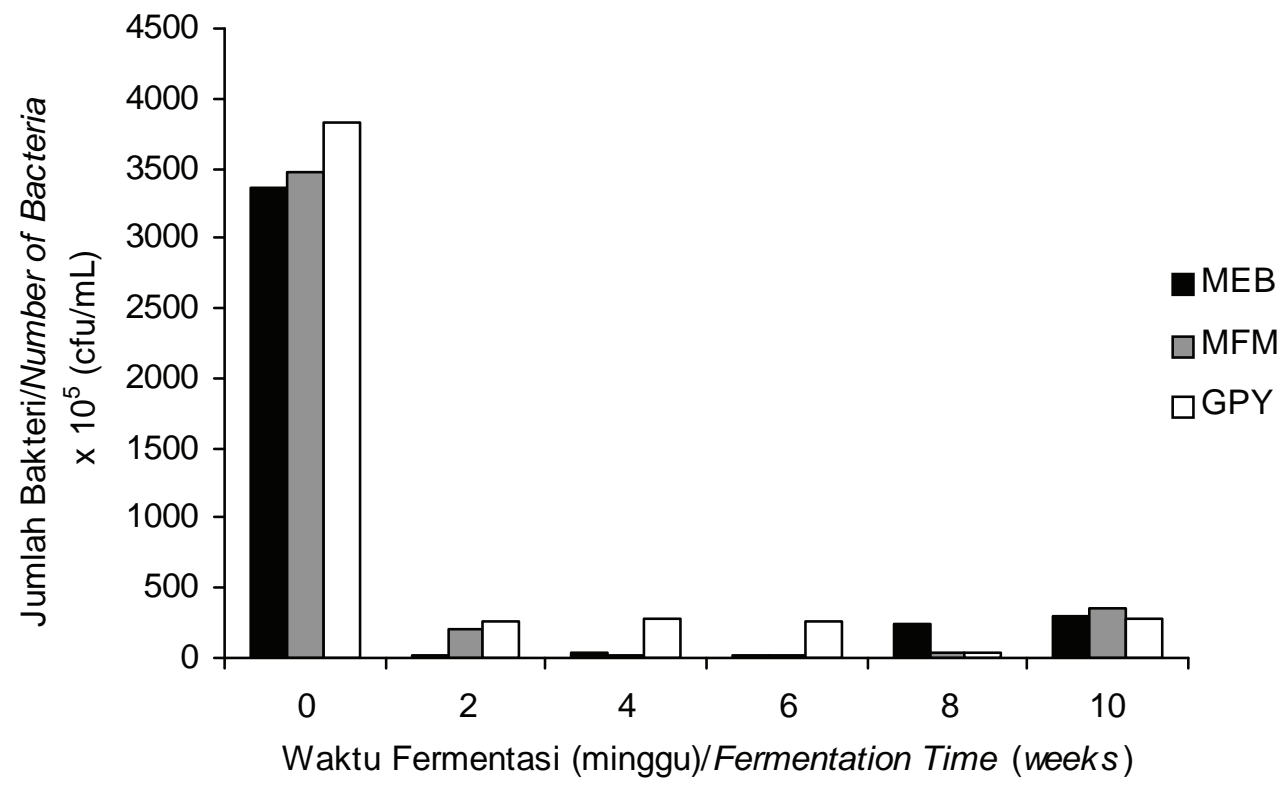

Gambar 1. Jumlah bakteri Vibrio parahaemolyticus pada kultur yang diberi ekstrak Streptomyces sp.

Figure. 1 Number of Vibrio parahaemolyticus in culture added with Streptomyces sp. extract. 


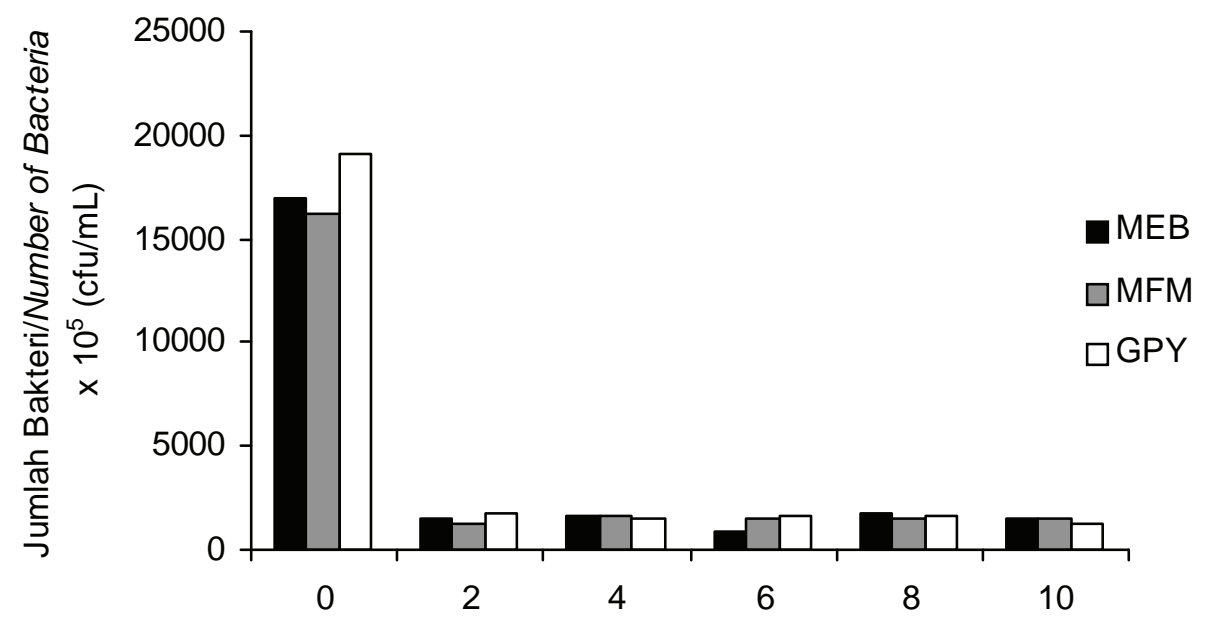

Waktu Fermentasi (minggu)/Fermentation Time (weeks)

Gambar 2. Jumlah bakteri Pseudomonas aerugenosa pada kultur yang diberi ekstrak Streptomyces sp.

Figure 2. Number of Pseudomonas aerugenosa in culture added with Streptomyces sp. extract.

ini dapat disimpulkan bahwa media MEB merupakan media terbaik untuk mengkultivasi Streptomyces yang memiliki aktivitas penghambatan bakteri uji $\mathrm{V}$. parahaemolyticus, diikuti oleh media MFM dan GPY. Di lain pihak, media MEB dan MFM sama baiknya dalam menghasilkan ekstrak $E$. rostratum yang menghasilkan ekstrak dengan bioaktivitas antibakteri V. parahaemolyticus sejak minggu ke-2 (Gambar 3). Medium MEB juga merupakan medium terbaik dalam menghasilkan jumlah ekstrak Streptomyces sp. dan E. rostratum yang memiliki bioaktivitas terhadap sel kanker (Chasanah et al., 2009).
Streptomyces sp. yang dikultivasi pada ke-3 media uji menghasilkan ekstrak yang memberikan efek penghambatan yang sama dan signifikan terhadap $P$. aerugenosa sejak minggu ke-2 dan relatif stabil sampai dengan minggu ke-10 (Gambar 2). Sebaliknya ekstrak E. rostratum menghasilkan ekstrak dengan bioaktivitas terhadap bakteri uji yang sama, $P$. aerugenosa, ketika dikultivasi pada media GPY pada minggu ke-2 (Gambar 4). Pengujian statistik Anova memberikan hasil bahwa jenis media dan waktu kultivasi memberikan pengaruh signifikan terhadap penghambatan bakteri uji $P$. aeruginosa $(P<0,05)$.

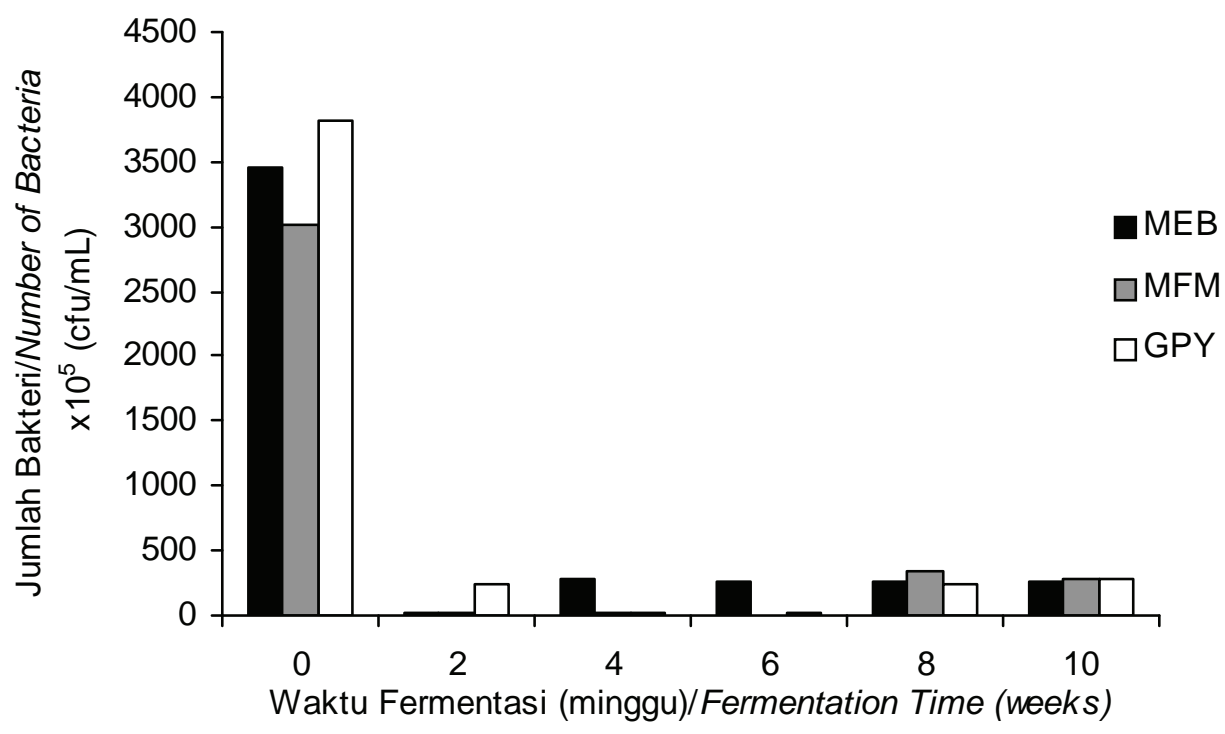

Gambar 3. Jumlah bakteri Vibrio parahaemolyticus pada kultur yang diberi ekstrak E. rostratum.

Figure 3. Number of Vibrio parahaemolyticus in culture added with E. rostratum extract. 


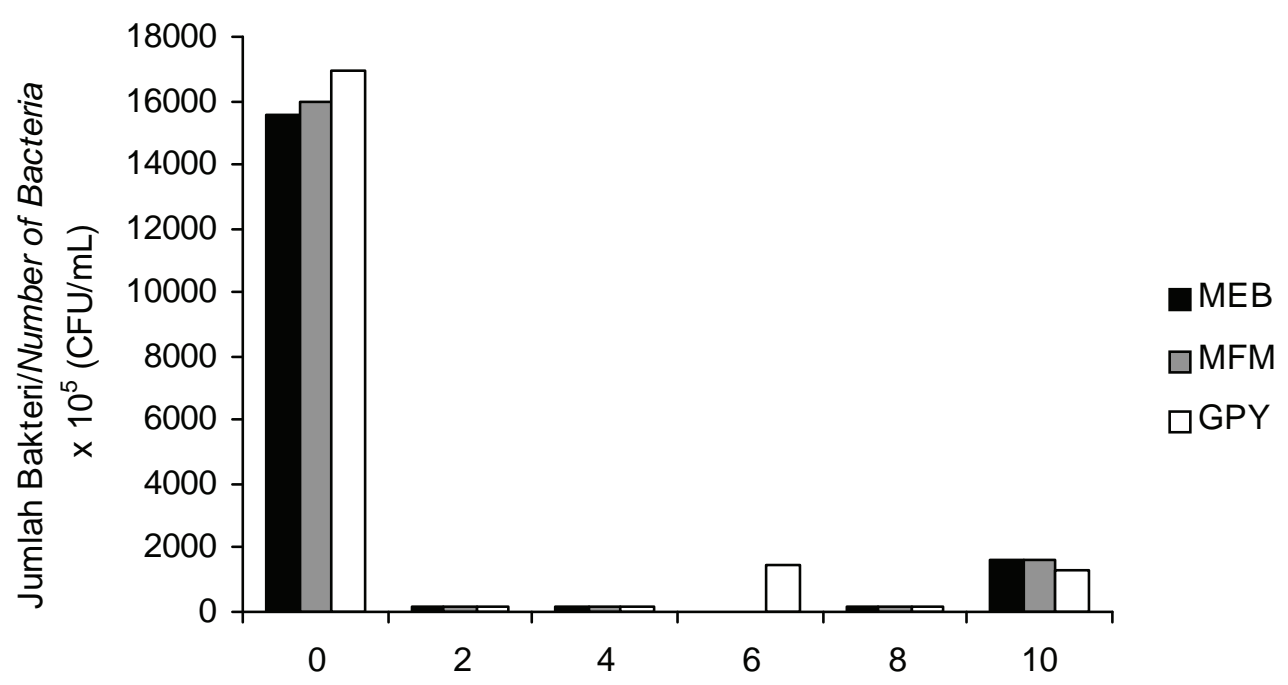

Waktu Fermentasi (minggu)/Fermentation Time (weeks)

Gambar 4. Jumlah bakteri Pseudomonas aerugenosa pada kultur yang diberi ekstrak E. rostratum. Figure 4. Number of Pseudomonas aerugenosa in culture added with E. rostratum extract.

Jumlah awal bakteri uji (V. parahaemolyticus dan $P$. aerugenosa) pada penelitian ini berkisar antara $10^{8}$ $-10^{9} \mathrm{cfu} / \mathrm{mL}$ atau absorbansi 0,6 - 0,7 pada OD 600 $\mathrm{nm}$ dan pada hasil terbaik, terjadi penurunan bakteri uji menjadi 20,3-27,1 x 105 cfu/mL (perlakuan ekstrak Streptomyces sp. pada V. parahaemolyticus) dan 92,7 x $10^{4}-14,4 \times 10^{5}$ (perlakuan ekstrak E. rostratum pada $P$. aerugenosa). Ini berarti bahwa terjadi penurunan jumlah bakteri 2-3 siklus log bakteri, yang mengindikasikan bahwa ekstrak kedua mikroba ini tidak terlalu hebat untuk mematikan sel bakteri patogen, tetapi dapat digunakan untuk mempertahankan bakteri patogen tersebut untuk tidak meningkat atau berkembang atau sebagai anti quorum sensing. Quorom sensing merupakan jumlah tertentu mikroba yang sangat penting dalam menentukan patogenisitas mikroba.

Secara umum, media memiliki peran yang sangat besar atas jumlah dan jenis metabolit yang dihasilkan oleh setiap mikroba yang dikultivasi. Pendekatan One Strain Many Compounds (OSMAC) yang disampaikan oleh Bode et al. (2002) merupakan strategi untuk mendapatkan peningkatan jumlah dan atau jenis metabolit aktif melalui modifikasi parameter kultivasi seperti jenis dan komposisi media, aerasi dan faktor Iain penentu keberhasilan kultivasi. MFM yang merupakan media paling miskin yang digunakan dalam studi ini yang terdiri dari $0,02 \%$ yeast extract dan $0,1 \%$ soluble starch, ternyata cukup mampu untuk menumbuhkan kedua mikroba yang dikultivasi dalam kondisi statis dan menghasilkan komponen aktibakteri, meskipun tidak terlalu kuat. Modifikasi akan komponen medium MFM ini dan atau modifikasi kondisi kultivasi seperti suhu, aerasi dan lain-lain. yang belum dilakukan dalam studi ini, merupakan area yang perlu dicoba untuk lebih mengoptimalkan media ini agar bioaktivitas antibakteri menjadi meningkat. Laporan Suthindhiran \& Kannabiran (2009) yang menyatakan bahwa media yang memiliki satu jenis sumber bahan nitrogen anorganik yeast extract mampu menghasilkan pertumbuhan dan bioaktivitas yang bagus. MFM merupakan media yang paling sederhana karena hanya memiliki pati sebagai sumber karbon dan yeast extract sebagai sumber nitrogen. MFM juga merupakan medium terbaik untuk mengkultivasi Aspergillus ustus MWF 26-08 dan menghasilkan senyawa antikanker sebaliknya media kaya MEB mendorong $A$. ustus menghasilkan senyawa aktif antioksidan (Pratitis et al.,2010).

\section{Identifikasi Senyawa}

Identifikasi awal terhadap ekstrak pekat kedua isolat dilakukan dengan NMR $500 \mathrm{MHz}$ dengan menggunakan pelarut $\mathrm{CDCl}_{3}$. Dari spektrum proton NMR diduga bahwa isolat ekstrak Streptomyces sp. mengandung senyawa alkaloid yang mengandung gugus aromatis (ä 7-8 ppm) dengan gugus alkil samping (ä 3-5 ppm) dan gugus amina (ä 1-3 ppm) (Gambar 5). Sedangkan dari spektrum NMR, ekstrak E. rostratum diduga mengandung senyawa peptida karena adanya serapan proton amida (ä 6-8 ppm), gugus metilen (ä 5-6 ppm), á-methine (ä 4-5 ppm) dan N-metil (ä 3-4 ppm) (Gambar 6). 


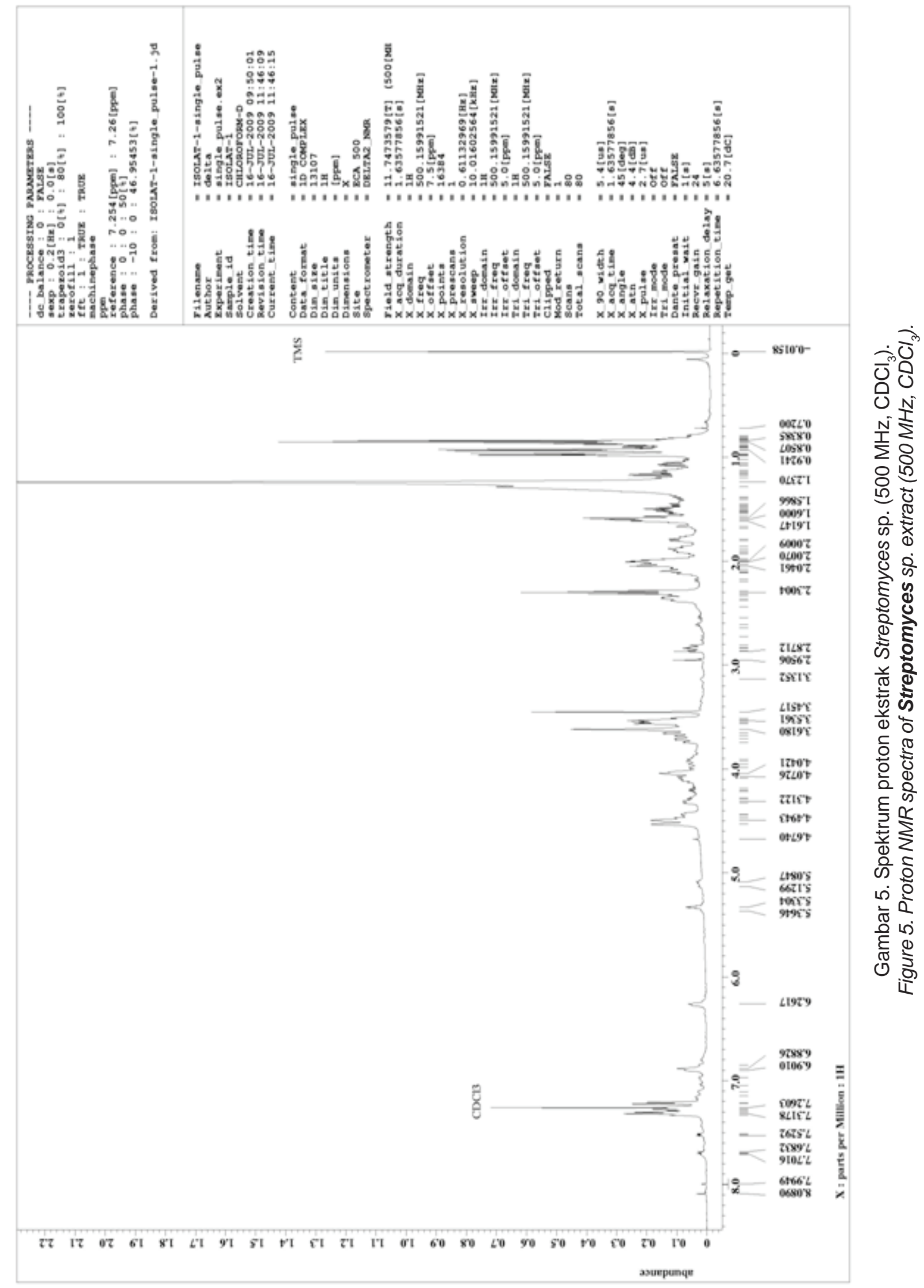




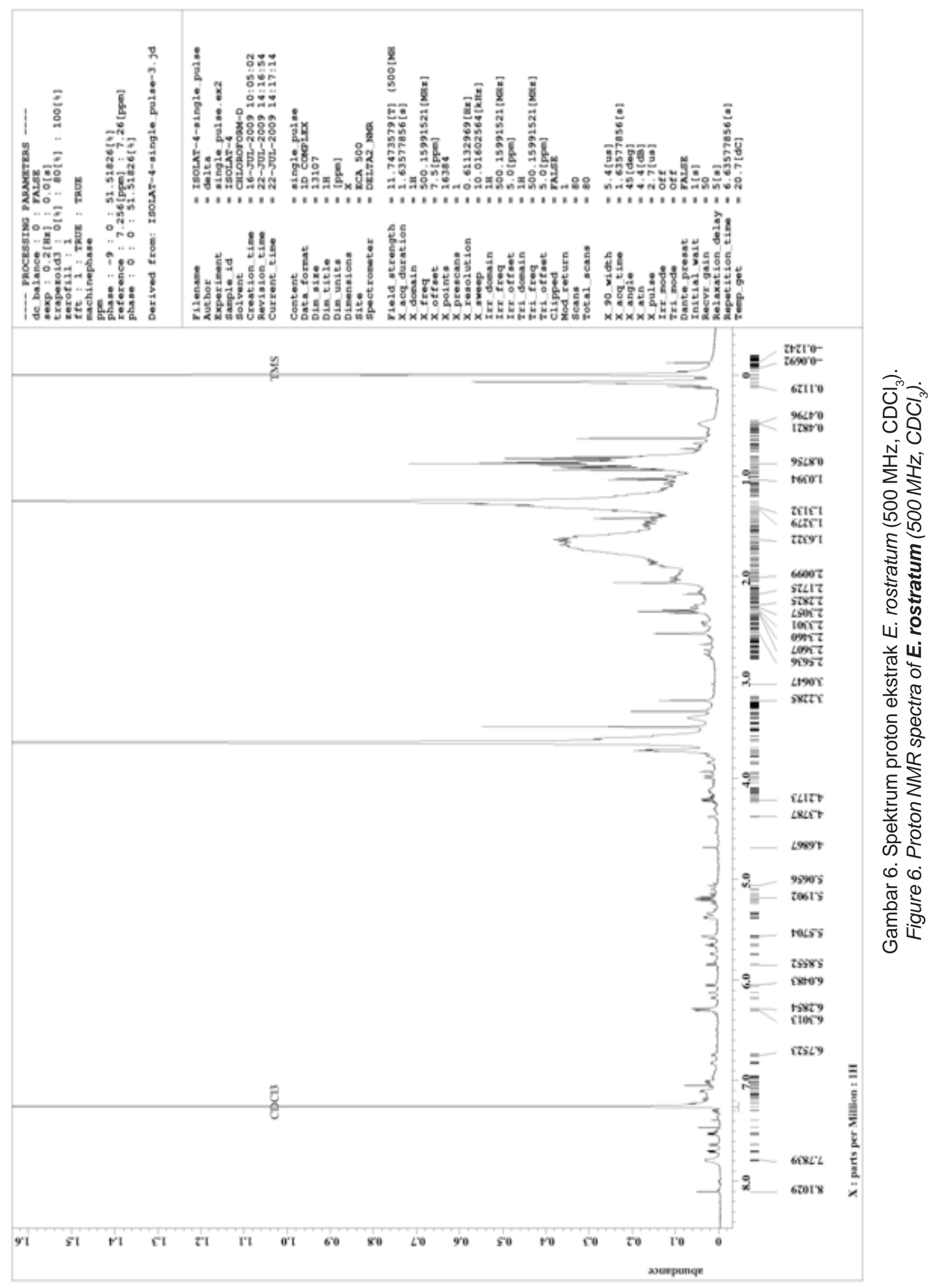




\section{KESIMPULAN}

1. Dalam studi ini, kedua isolat tidak berpotensi sebagai penghasil senyawa antioksidan yang ditunjukkan dengan nilai $\mathrm{IC}_{50}$ penghambatan radikal bebas sebesar 456,5-507,2 ppm.

2. Ekstrak kedua mikroba (Streptomyces sp. dan E. rostratum) tidak terlalu hebat untuk mematikan sel bakteri patogen uji ( $V$. parahaemolyticus dan $P$. aerugenosa), tetapi dapat digunakan untuk mempertahankan bakteri patogen tersebut untuk tidak meningkat atau berkembang, atau sebagai bahan anti quorum sensing. Kemampuan penghambatan bakteri uji sebesar 2-3 siklus log.

3. MEB merupakan media terbaik untuk mengkultivasi kedua mikroba dalam menghasilkan bahan antibakteri $V$. parahaemolyticus dan $P$. aerugenosa, diikuti oleh medium MFM.

4. Identifikasi pendahuluan berdasarkan spektra NMR terhadap jenis senyawa aktif yang terkandung dalam ekstrak Streptomyces sp. dan E. rostratum berturut-turut menunjukkan bahwa senyawa aktif antibakteri dalam ekstrak tersebut termasuk dalam golongan alkaloid dan peptida.

\section{DAFTAR PUSTAKA}

Auroman, I.O. and Coppet, L.S. 1997. Antioxidant Methology: In Vivo and In Vitro Concept. AOCS Press. Champaign.

Blois, M.S. 1958. Antioxidant determination by the use of a stable free radical. Nature. 181: 1199-1200.

Bode, H.B, Bethe, B., H^fs ,R., and Zeeck, A. 2002. Big effects from small changes: Possible ways to explore nature's chemical diversity. Chem. Bio. Chem. 3: 619-627.

Chasanah, E., Januar, H.I., Bourne, D., Liptrot, C., and Wright A. 2009. Screening of anticancer activity of fungi derived from Indonesian marine sponges. Journal of Marine and Fisheries Postharvest and Biotechnology, special edition in conjuction with World Ocean Conference, Manado, May 11-14, 2009.

Chasanah, E., Januar, H.I., Liptrot, C., Doyle, J., and Wright, A. 2006. Screening of Anticancer and
Antimicrobial of Marine Invertebrate Extract from Indonesia. Paper presented at International Seminar on Natural Products (MANAPRO), Queenstown, New Zealand. February 5-7, 2007.

Jeon, Y.J. and Kim, S.K. 2000. Effect of antimicrobial activity by chitosan oligosaccharide $\mathrm{N}$-conjugated with asparagine. Journal of Microbiology and Biotechnology, 11, 281e286.2001.

Li, Y., Li, X., Lee, U., Kang, J.S., Choi, H.D., and Son, B.W. 2006. A new radical scavenging anthracene glycoside, asperflavin ribofuranoside, and polyketides from a marine isolat of the fungus Microsporum. Chem. Pharm. Bull. 54(6): 882-883.

Mahyidin, N.A. 2008. Actinomycetes and Fungi Assosiated with Marine Invertebrates: A Potential Source of Bioctive Compounds. A Thesis. University of Canterbury. New Zealand

Meletiadis, J., Meis, J.F. G. M, Mouton, J.W., and Verweij, P.E. 2001. Analysis of growth characteristics of filamentous fungi in different nutrient media. $\mathrm{J}$ of Clinical Microbiol. 39(2): 478-484.

Nursid, M., Pratitis, A., dan Chasanah, E. 2010. Kultivasi kapang MFW 01-08 yang diisolasi dari Ascidia Aplidium longithorax dan uji aktivitas sitotoksiknya terhadap sel kanker payudara T47D. J. Pascapanen dan Bioteknologi Kelautan dan Perikanan. 5(2): 103-110.

Pratitis, A, Patantis, G., Mangunwardoyo W., dan Chasanah, E. 2010. Produksi senyawa bioaktif dari Aspergillus ustus MFW 26-08 yang berasosiasi dengan spons laut dalam berbagai media. J. Pascapanen dan Bioteknologi Kelautan dan Perikanan. 5(2): 93-102.

Suthindhiran, K. and Kannabiran, K. 2009. Cytotoxic and antimicrobial potential of actinomycete species Saccharopolyspora salina VITSDK4 isolated from the Bay of Bengal Coast of India. American Journal of Infectious Diseases. 5(2): 90-98.

Strainer, H.M. 1990. The Australian Collection of Marine Microorganisms. 4 th Ed. Sir George Fisher Centre for Tropical Marine Studies.

Zhang, D. and Son, B.W. 2007. Chemical Studies on the Bioactive Metbolites from Marine Derived-Fungi MFB604 \& MFC353. Natural Products Chemistry Laboratory. Pukyong National University. Busan. Korae. 